\title{
A microbiological assay for the measurement of methotrexate in biological fluids
}

\author{
GC ICKE, RE DAVIS, J THOM \\ From the Department of Haematology, Royal Perth Hospital, Perth, Western Australia
}

SUMMARY A microbiological assay for the measurement of methotrexate has been designed, using a chloramphenicol resistant mutant of Lactobacillus casei as the test organism. The method is simple, precise and inexpensive. Results are not significantly different from those obtained using a methotrexate radioassay kit employing a competitive protein binding technique. However, where patients are being treated with co-trimoxazole, the competitive protein binding technique is unsuitable for measuring methotrexate levels due to the cross reactivity of the binder. This is not a problem with the microbiological assay described here, which is able to measure methotrexate in the presence of large doses of trimethoprim.

The methods were not affected by the presence of seven commonly encountered antibiotics. These had negligible effect on either method up to concentrations of $100 \mathrm{mg} / \mathrm{l}$.

Methotrexate, 4-amino-10 methyl pteroylglutamic acid, is a cytotoxic drug which has wide clinical use in the treatment of neoplastic disease. ${ }^{1-4}$ It is also considered a most effective agent in the treatment of severe psoriasis. $^{5}$ Methotrexate achieves its cytotoxic effect by acting as a spurious substrate for dihydrofolate reductase which prevents the reduction of dihydrofolate to tetrahydrofolate. ${ }^{6}$ This in turn blocks the formation of 5,10-methylene tetrahydrofolate and thus synthesis of thymidine and DNA. Recently there has been extensive use of high dose methotrexate therapy followed by rescue with 5-formyl tetrahydrofolate (folinic acid). This means that high concentrations of the drug can be attained with free intracellular methotrexate in the rapidly dividing tumour cells which ensures the maximum cytotoxic effect. 5-formyl tetrahydrofolate can be metabolised to 5, 10-methylene tetrahydrofolate without the need for dihydrofolate reductase and is therefore able to bypass the block.

The two most severe side effects of high dose methotrexate treatment are myelosuppression and renal failure which have been reported to have a $6 \%$ mortality. ${ }^{78}$

The use of high dose methotrexate requires careful monitoring of the patient's serum concentrations of the drug and a number of methods have been designed for this purpose..$^{9-13}$ One commonly used method is based on competitive protein binding, ${ }^{12}$

Accepted for publication 1 June 1983 but this suffers from cross reactivity with drugs such as trimethoprim that bind strongly to the bacteriab dihydrofolate reductase used in the assay.

There are occasions when patients are treate $\phi^{\circ}$ with both methotrexate and trimethoprim (co? trimoxazole) and in these patients the competitive protein binding assay gives erroneous results. Although the manufacturers of the kit claim a cross reactivity of only $15 \%$, in our hands the cross reactivity has been much higher than this.

We describe here a microbiological method for the measurement of methotrexate using a chloramphenicol resistant strain of Lactobacillus casei (ATCC 7469) as the test organism which is simple, precise and unaffected by the presence of trimethoprim.

\section{Material and methods}

The method is essentially a modification of the automated microbiological folate method described by Davis et $a^{14}$ and utilises the same chloramphenicol resistant strain of $L$ case $i$ as the test organism, and the same asay medium.

\section{STANDARDS}

A stock solution was prepared by taking $1 \mathrm{ml}$ of methotrexate solution (Lederle) containing $1 \mathrm{mg} / \mathrm{ml}$ and diluting this to $1000 \mathrm{ml}(1 \mathrm{mg} / \mathrm{l})$ with distilled water. This solution was found to be stable at $4{ }^{\circ} \mathrm{C}$ for at least six months. On the day of the test the 116 
Table 1 Preparation of methotrexate standards for the microbiological assay

\begin{tabular}{|c|c|c|c|c|c|c|c|c|c|c|}
\hline $\begin{array}{l}\text { Distilled water }(\mathrm{ml}) \\
\text { Methotrexate working solution (ml) } \\
\text { Concentration (ng/l) }\end{array}$ & $\begin{array}{l}5 \cdot 0 \\
0 \\
0\end{array}$ & $\begin{array}{r}4 \cdot 75 \\
0 \cdot 25 \\
50\end{array}$ & $\begin{array}{l}4 \cdot 62 \\
0 \cdot 38 \\
75\end{array}$ & $\begin{array}{r}4 \cdot 5 \\
0 \cdot 5 \\
100\end{array}$ & $\begin{array}{r}4 \cdot 25 \\
0 \cdot 75 \\
150\end{array}$ & $\begin{array}{r}4 \cdot 0 \\
1 \cdot 0 \\
200\end{array}$ & $\begin{array}{r}3 \cdot 75 \\
1 \cdot 25 \\
250\end{array}$ & $\begin{array}{r}3.5 \\
1 \cdot 5 \\
300\end{array}$ & $\begin{array}{r}3 \cdot 0 \\
2 \cdot 0 \\
400\end{array}$ & $\begin{array}{r}2 \cdot 5 \\
2 \cdot 5 \\
500\end{array}$ \\
\hline $\begin{array}{l}\text { or } \\
\text { (nmol/l) }\end{array}$ & 0 & $0 \cdot 11$ & $0 \cdot 17$ & 0.22 & 0.33 & 0.44 & 0.55 & 0.66 & 0.88 & $1 \cdot 1$ \\
\hline
\end{tabular}

stock solution was further diluted $1 / 1000$ giving a concentration of $1 \mu \mathrm{g} / \mathrm{l}$. This working solution was used to prepare the final standard solutions as shown in the protocol (Table 1).

\section{CONTROL SERUM}

A serum control was prepared by adding a known quantity of methotrexate to pooled sera. The sample was divided into aliquots and lyophilised. On the day of the assay it was reconstituted with distilled water and suitable dilutions made.

\section{ANTIBIOTICS}

The sensitivity of the chloramphenicol resistant $L$ case $i$ was tested against a series of methotrexate control samples, to which, the following antibiotics were added at a concentration of $100 \mathrm{mg} / \mathrm{l}$ : cefotaxime, streptomycin, tetracycline, amoxycillin, benzylpenicillin and gentamicin. These samples were also tested by the isotopic assay.

Aqueous solutions of the same antibiotics at concentrations of $10 \mathrm{mg} / \mathrm{l}$ were treated as unknown samples and assayed by the microbiological assay.

To one methotrexate control serum trimethoprim was added to a concentration of $4 \mathrm{mg} / \mathrm{l}$ and assayed by both methods.

\section{LEUCOVORIN (LEDERLE "FOLINIC ACID")}

Various concentrations of leucovorin were added to aqueous methotrexate solutions containing 10,1 and $0.1 \mu \mathrm{mol}$ of methotrexate respectively. These were assayed by both methods.

\section{ISOTOPIC ASSAY KIT}

The competitive protein binding kit was obtained from the New England Enzyme Centre, Boston, US and was used in accordance with the manufacturer's recommendations.

PROCEDURE FOR THE MICROBIOLOGICAL ASSAY A suitable quantity of double strength assay medium $^{14}$ was diluted with an equal volume of distilled water. To each litre of single strength medium was added $10 \mathrm{mg}$ chloramphenicol, $0.6 \mathrm{ml}$ of an overnight culture of the test organism with an absorbance of 0.7 , and $7.5 \mathrm{ml}$ of $2 \mu \mathrm{g} / 1$ folic acid solution. The inoculated medium was mixed continuously on a magnetic stirrer.

Suitable dilutions were made of the test sera in distilled water. These will vary depending on the dosage of methotrexate administered and the period of time elapsed since the last dose. We have found that a range of dilutions from $1 / 50$ through to $1 /$ 10000 satisfactory, however where very large doses of methotrexate are used, higher dilutions may be necessary.

Fifty microlitres of the methotrexate standards, the serum dilutions and the control serum dilutions (in duplicate) were placed into plastic disposable tubes and diluted $1 / 100$ by adding $4.95 \mathrm{ml}$ of the prepared medium to each and then incubated at $37^{\circ} \mathrm{C}$ for $16 \mathrm{~h}$. After incubation, the contents of the tubes were mixed and the absorbance read in a spectrophotometer fitted with a flow cell.

\section{Calculation}

(i) From the absorbance of the standards the lowest methotrexate concentration which inhibits the growth of the test organism was determined.

(ii) Similarly the highest dilution in the test and control tube at which inhibition occurs was found.

(iii) Multiplying the concentration in (i) above by the serum dilution obtained in (ii) gave the result in

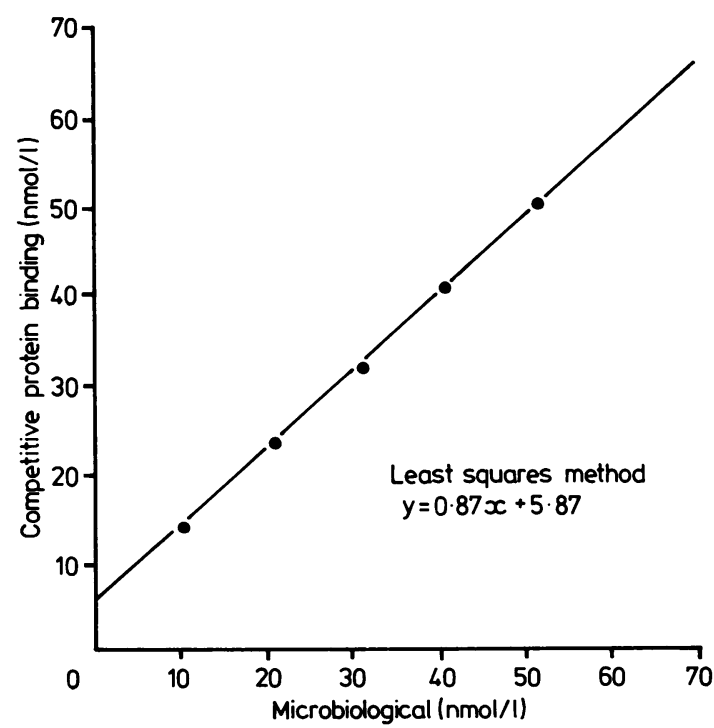

Regression line of competitive protein binding assay against microbiological assay 
$\mathrm{ng} / \mathrm{l}$. This can be converted to $\mathrm{nmol} / \mathrm{l}$ by multiplying by $2 \cdot 2 / 1000$.

\section{Results}

Sixteen sera and three CSF samples from hospital patients being treated with methotrexate were assayed by both methods and the results are shown in Table 2. A regression line of competitive protein binding assay against microbiological assay is shown in the Figure. The correlation coefficient was 0.99 $(<0.001)$. The mean of the microbiological assay was $511.3 \mathrm{nmol} / 1$ and the mean of the isotopic assay was $513.8 \mathrm{nmol} / \mathrm{l}$. There was no significant difference between the means (paired $t$ test, $t=0.64$ ).

The methotrexate control sample to which trimethoprim had been added was assayed by both methods, as were serum samples from four patients being treated with trimethoprim (Septrin) and methotrexate. Results are shown in Table 3.

The results of the methotrexate control samples to which the various antibiotics were added are listed in Table 4. Aqueous solutions at concentrations of $10 \mathrm{mg} / \mathrm{l}$ of the antibiotics showed inhibition equivalent to $<1 \mathrm{nmol} / 1$ of methotrexate when assayed by the microbiological assay.

Methotrexate concentrations of $10 \mu \mathrm{mol}$ were shown to be unaffected by up to $250 \mathrm{mg} / \mathrm{l}$ of leucovorin in either method. Similarly neither method was affected by $100 \mathrm{mg} / \mathrm{l}$ of leucovorin with methotrexate concentrations of $1 \mu \mathrm{mol}$, or $0 \cdot 1 \mu \mathrm{mol}$.

One sample was assayed 20 times in 5 different batches by the microbiological method. Results

Table 2 Comparison of results from two methods for measuring methotrexate

\begin{tabular}{|c|c|c|c|}
\hline & & 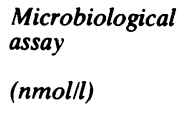 & $\begin{array}{l}\text { Competitive } \\
\text { protein binding } \\
\text { assay } \\
\text { (nmolll) }\end{array}$ \\
\hline Sera & $\begin{array}{r}1 \\
2 \\
3 \\
4 \\
5 \\
6 \\
7 \\
7 \\
8 \\
9 \\
10 \\
11 \\
12 \\
13 \\
14 \\
15 \\
16\end{array}$ & $\begin{array}{r}112 \cdot 7 \\
28 \cdot 2 \\
2 \cdot 6 \\
101 \cdot 0 \\
10 \cdot 6 \\
21 \cdot 1 \\
197 \cdot 1 \\
7 \cdot 0 \\
56 \cdot 3 \\
3 \cdot 2 \\
12 \cdot 3 \\
154 \cdot 0 \\
24 \cdot 6 \\
1815 \cdot 0 \\
536 \cdot 3 \\
3 \cdot 3\end{array}$ & $\begin{array}{r}90.2 \\
24 \cdot 2 \\
3 \cdot 5 \\
110 \cdot 0 \\
13 \cdot 2 \\
20 \cdot 9 \\
176 \cdot 0 \\
8 \cdot 3 \\
55 \cdot 0 \\
5 \cdot 2 \\
12 \cdot 5 \\
130.9 \\
28 \cdot 8 \\
1793 \cdot 0 \\
475 \cdot 0 \\
4.0\end{array}$ \\
\hline CSF & $\begin{array}{l}1 \\
2 \\
3\end{array}$ & $\begin{array}{r}10.6 \\
1460 \cdot 0 \\
11 \cdot 0\end{array}$ & $\begin{array}{r}18 \cdot 7 \\
1518 \cdot 0 \\
14 \cdot 5\end{array}$ \\
\hline
\end{tabular}

Correlation coefficient $0.99(p<0.001)$.
Table 3 Comparison of results from two methods for measuring methotrexate in the presence of trimethoprim

\begin{tabular}{lcl}
\hline Sample & $\begin{array}{l}\text { Microbiological } \\
\text { assay (nmoll) }\end{array}$ & $\begin{array}{l}\text { Competitive } \\
\text { protein binding } \\
\text { assay (nmoll) }\end{array}$ \\
\hline 1 & 66 & 1144 \\
2 & 308 & 1188 \\
4 & 193 & 880 \\
Control serum & 58 & 660 \\
A & 98 & 101 \\
Control serum & & \\
B & 96 & 924 \\
\hline
\end{tabular}

Both control sera containined $100 \mathrm{nmol} / \mathrm{l}$ methotrexate and in addition control sera B contained $4 \mathrm{mg} / \mathrm{l}$ trimethoprim.

ranged from $275-344 \mathrm{nmol} / 1$, with a mean of 308.9 , SD of 24.6 and coefficient of variation of $7.9 \%$.

\section{Discussion}

The concurrent treatment with co-trimoxazole and methotrexate in some patients can create difficulties in monitoring methotrexate concentrations by protein binding methods. The cross reactivity of trimethoprim with the protein binding assay was found to be considerably greater than the $15 \%$ claimed by the manufacturer (Table 3 ). Trimetho prim was added to a methotrexate control serum at concentration of $4 \mathrm{mg} / \mathrm{l}$. This concentration was used as it is representative of peak serum concentrations of trimethoprim found in patients receiving co-trimoxazole. An expected result of $100 \mathrm{nmol} / \mathrm{l}$ of methotrexate yielded a recovery of $96 \%$ by the microbiological assay and $924 \%$ by the protein binding assay. Serum from patients on both methotrexate and co-trimoxazole demonstrated similar discrepancies with the protein binding assay (Table 3 ).

Kits based on competitive binding for measuring methotrexate which use a dihydrofolate reductase derived from bacteria can be expected to give spuri-

Table 4 Comparison of results from two methods for measuring methotrexate in the presence of various antibiotics

\begin{tabular}{lcc}
\hline Antibiotic & $\begin{array}{c}\text { Microbiological } \\
\text { assay (nmolll) }\end{array}$ & $\begin{array}{l}\text { Competitive } \\
\text { protein binding } \\
\text { assay (nmolll) }\end{array}$ \\
\hline Cefotaxime & 99 & 100 \\
Tetracycline & 99 & 98 \\
Streptomycin & 99 & 100 \\
Benzyl penicillin & 111 & 108 \\
Amoxil & 99 & 95 \\
Gentamicin & 110 & 99 \\
Trimethoprim & 96 & 924 \\
\hline
\end{tabular}

All samples contained $100 \mathrm{nmol} / \mathrm{l}$ of methotrexate and $100 \mathrm{mg} / \mathrm{l}$ of each antibiotic, except for trimethoprim which was used at a concentration of $4 \mathrm{mg} / \mathrm{l}$. 
ous high results in the presence of normal therapeutic levels of trimethoprim. Trimethoprim is specifically directed against the bacterial dihydrofolate reductase used as a binder in this assay and competitive binding protein kits are therefore unsuitable for use in the presence of this agent.

Aqueous solutions of seven commonly encountered antibiotics at concentrations equivalent to peak serum levels had no inhibitory effect on the microbiological assay.

$L$ casei appeared to be particularly sensitive to inhibition by methotrexate and the method was found to be capable of detecting as little as $0.5 \mathrm{nmol}$ of this drug. The serum dilutions required for the microbiological assay result in concentrations of trimethoprim and other antibiotics tested which were too low to affect growth of the test organisms (Table 4). In a preliminary study, the addition of leucovorin to a limited range of methotrexate concentrations revealed similar results by both methods with only limited interference seen in the lower methotrexate range.

In the lower range results were marginally less than those obtained by the competitive protein binding assay (Figure); however there was no statistically significant difference between the means of a series of samples (Table 2).

The use of a chloramphenicol-resistant strain of $L$ case $i$ as the test organism, greatly simplified the procedure and had the advantage that aseptic manoeuvres were not necessary, which permits the use of automated diluting systems. The microbiological inhibition assay using $L$ casei has been used in this laboratory for over three years.

It takes longer to obtain results using this method than the radioisotope dilution assay as overnight incubation is required. However, the microbiological assay has been shown to give valid results of methotrexate and unlike the radioisotope dilution assay is unaffected by the presence of trimethoprim. The test is cheap and can be run for approximately one sixth of the cost of the radioisotope dilution assay in our laboratory.
We wish to thank Dr JM Jackson for his advice and encouragement.

\section{References}

' Djerassi I, Abir E, Rover GL, Treat CL. Long term remissions of childhood acute leukaemia: Use of infrequent infusions of methotrexate; supportive roles of platelet infusions and citrovorum factor. Clin Pediatr 1966;5:502-9.

2 Jaffe N, Frei E, Watts H, Traggis D. High dose methotrexate in osteogenic sarcoma: A 5-year experience: Cancer Treat Rep 1978;62:259-64.

${ }^{3}$ Truman S, Coleman M, Silver RT. Treatment of resistant phase lymphoma with "high dose" methotrexate and folinic acid rescue. Proc Am Assoc Cancer Res 1976;17:302.

4 Djerassi I, Rominger CJ, Kim JS, Turchi J, Suvansri U, Hughes D. Phase 1 study of methotrexate with citrovorum factor in patients with lung cancer. Cancer 1972;30:22-6.

${ }^{5}$ Baker H, Fry L, Pegum JS. In: Rook A, ed. Recent advances in dermatology. London: Churchill-Livingstone, 1973.

- Paxton JW. High dose methotrexate therapy-An area of uncertainty. Aust NZ J Med 1979;9:722-32.

' Von Hoff DD, Penta JS, Helman LJ, Slavik K. Incidence of drug related deaths secondary to high-dose methotrexate and citrovorum factor administration. Cancer Treat Rep 1977;61:745-7.

8 Pitman SW. Clinical trial of high-dose methotrexate with citrovorum factor. Toxicological and therapeutic observations. Cancer Chemother Rep 1975;62:381-3.

${ }^{9}$ Kinkade JM, Vogler WR, Dayton PG. Plasma levels of methotrexate in cancer patients as studied by an improved spectrophotofluorometric method. Biochem Med 1974;10: 327-50.

${ }^{10}$ Noble WC, White P, Baker H. Assay of therapeutic doses of methotrexate in body fluids of patients with psoriasis. $J$ Invest Dermatol 1975;64:69-76.

" Raso V, Schreiber R. A rapid and specific radioimmunoassay for methotrexate. Cancer Res 1975;35:1407-10.

${ }^{12}$ Myers CE, Lippman ME, Eliot HM, Chabner BA. Competitive protein binding assay of methotrexate. Proc Natl Acad Sci (Wash) 1975;72:3683-6.

${ }^{13}$ Falk FC, Clark DR, Kalman SM, Long TF. Enzymatic assay for methotrexate in serum and cerebrospinal fluid. Clin Chem 1976;22:785-8.

14 Davis RE, Nicol DJ, Kelly A. An automated method for the measurement of folate activity. J Clin Pathol 1970;23:47-53.

Requests for reprints to: Mr GC Icke, Department of Haematology, Royal Perth Hospital, Perth, Western Australia. 